\title{
An electron-beam-grafted ETFE alkaline anion-exchange membrane in metal-cation-free solid-state alkaline fuel cells.
}

\section{John R. Varcoe* and Robert C. T. Slade}

Chemistry, The University of Surrey, Guildford GU2 7XH, United Kingdom.

Tel: +44 (0)1483682616 Fax: +44 (0)1483 686851

*Author for correspondence: E-mail: j.varcoe@ surrey.ac.uk

A novel, physically strong, quaternary-ammonium-functionalised radiation-grafted ETFE alkaline anion-exchange membrane (AAEM) has been developed for application in fuel cells without undesirable addition of $\mathrm{M}^{+} \mathrm{OH}^{-}$into the anode fuel stream, thereby facilitating stable performances and long term operational lifetimes. A promising $\mathrm{H}_{2} / \mathrm{O}_{2}$ fuel cell peak power performance of $130 \mathrm{~mW} \mathrm{~cm} \mathrm{~cm}^{-2}$ was obtained for an alkaline membrane electrode assembly, while a maximum power density of 8.5 $\mathrm{mW} \mathrm{cm}{ }^{-2}$ was obtained in a metal-cation-free methanol/ $\mathrm{O}_{2}$ fuel cell. Mass transport phenomena in the electrodes and inadequate interface between the membrane and electrodes were identified as the major limiters of power performance; the need for electrode architectures to be optimised for alkaline membrane fuel cells was identified.

Keywords: Radiation-grafting; Alkaline anion-exchange membrane; Fuel cell; ETFE; Methanol; Metal-cation-free alkaline membrane electrode assembly 


\section{Introduction}

There is an increasing interest in the application of alkaline anion-exchange membranes (AAEMs, membranes that conduct hydroxide ions, the high $\mathrm{pH}$ equivalent to proton-exchange membranes such as Nafion ${ }^{\circledR}$ from Du Pont) in metalcation-free all-solid-state alkaline fuel cells. The advantages, disadvantages and rationale of this have been explained in detail in a recent review [1]. A recent breakthrough towards this target was the development of an alkaline polymer electrochemical interface, an $\mathrm{OH}^{-}$-conducting analogue of the acidic Nafiondispersions used in proton-exchange membrane (PEM) membrane electrode assemblies (MEAs) [2]; this interface enables the preparation of metal-cation-free alkaline MEAs, which improves performances and allows long-term operation of the resulting fuel cells with direct methanol oxidation at the anode (generating $\mathrm{CO}_{2}$ ) and $\mathrm{CO}_{2}$-containing air supplied to the cathode. Without this type of alkaline binding polymer, non-ideal strategies have been employed, such as addition of high concentrations of $\mathrm{NaOH} / \mathrm{KOH}$ into the methanol fuel supply [3-5].

The authors' previous work on the development of thermally and chemically stable AAEMs for fuel cells has centred on the introduction of quaternary ammonium functionality via radiation-grafting (using high radiation doses of $\gamma$-rays) onto poly(tetrafluoroethylene-co-hexafluoropropylene), FEP, preformed membranes [6,7]; these membranes exhibited conductivities between $0.010-0.035 \mathrm{~S} \mathrm{~cm}^{-1}$ in the temperature range $20-80^{\circ} \mathrm{C}$ when fully hydrated (acceptable for application in fuel cells as these conductivities correspond to $20-33 \%$ of the levels exhibited by Nafion ${ }^{\circledR}-115$ under the same conditions) [8]. The major problem encountered with the FEP-based AAEMs, with respect to application in fuel cells, is the lack of physical strength and stability; the conductive AAEMs could not be tested in fuel cells on 
safety grounds (especially with $\mathrm{H}_{2} / \mathrm{O}_{2}$ gases) as physical failure was unavoidable. The source of this physical weakness is the lack of stability to radiation of FEP; to achieve AAEMs of acceptable conductivity required radiation doses that degraded the FEP polymer chains to an unacceptable level.

The advance reported in this communication relates to the development of an AAEM where the FEP has been replaced by a poly(ethylene-co-tetrafluoroethylene), ETFE, preformed film. Partially fluorinated films such as ETFE and poly(vinylidene fluoride), PVDF, exhibit superior radiation-resistance over fully fluorinated films [9] (radiation-induced radical formation via $\mathrm{C}-\mathrm{H}$ bond fission dominate in partially fluorinated polymers, while undesirable C-C bond fission becomes significant in fully-fluorinated polymers); PVDF is, however, not suitable as a base material as it chemically degrades (dehydrofluorination) in alkaline environments [7]. This communication reports highly promising initial performances when metal-cation-free MEAs containing a radiation-grafted ETFE AAEM were evaluated in $\mathrm{H}_{2} / \mathrm{O}_{2}$ and direct methanol fuel cells (DMFCs).

\section{Experimental}

\subsection{Membrane preparation}

The ETFE-based AAEM was produced using widely reported methods $[6,8]$ and so the procedure will only be summarised here (Scheme 1): ETFE (25 $\mu \mathrm{m}$ thick, Nowoflon ET-6235 film, Nowofol, Germany) was irradiated in air with an electronbeam to a total dose of 7 MRad. The irradiated ETFE was then submerged in nitrogen-purged vinylbenzyl chloride monomer (VBC, Dow Chemicals, 1:1 meta/para- mix, used as received without removal of inhibitors) at $60^{\circ} \mathrm{C}$ for $120 \mathrm{~h}$. The resulting ETFE-g-poly(vinylbenzyl chloride) copolymer was then immersed in 
aqueous trimethylamine (50\%wt, Acros Organics) at room temperature for $4 \mathrm{~h}$. Immersion of the resulting anion-exchange membrane in aqueous potassium hydroxide $\left(1 \mathrm{~mol} \mathrm{dm}^{-3}\right)$ for $1 \mathrm{~h}$ yielded the target AAEM. The AAEM produced (thickness $=51 \pm 2 \mu \mathrm{m}$ when fully hydrated) had an ion-exchange capacity of $1.42 \pm$ $0.09 \times 10^{-3} \mathrm{~mol}\left(\mathrm{OH}^{-}\right) \mathrm{g}^{-1}$ (dry polymer), as determined using a standard back titration method [8] (cf. Nafion ${ }^{\circledR}-115$ has an ion-exchange capacity of $0.92 \pm 0.01 \times 10^{-3}$ $\operatorname{mol}\left(\mathrm{H}^{+}\right) \mathrm{g}^{-1}$ (dry polymer) [10], and a fully hydrated thickness of $\left.153 \pm 3 \mu \mathrm{m}\right)$. The short-term thermal stability of the AAEM was determined to be $130 \pm 10^{\circ} \mathrm{C}$ in $60 \mathrm{~cm}^{3}$ $\min ^{-1}$ of flowing air (TA instruments TGA Q500 thermogravimetric analyser); detailed studies into the long-term thermal stability and conductivity (different temperatures and different relative humidities) of this class of AAEM are now being undertaken.

\subsection{Preparation of the membrane electrode assemblies}

For initial $\mathrm{H}_{2} / \mathrm{O}_{2}$ testing, the anode and cathode Pt/C electrodes (E-Tek, $0.5 \mathrm{mg} \mathrm{cm}{ }^{-2}$ $\mathrm{Pt} / \mathrm{C}(20 \% \mathrm{wt})$ on carbon cloth with unspecified (proprietary) loadings of PTFE as binder) were spray-treated with poly(vinylbenzyl chloride) (Aldrich, used as received) to a loading of $0.51 \pm 0.01 \mathrm{mg} \mathrm{cm}^{-2}$ using an airbrush and ethyl acetate as solvent; subsequent immersion in undiluted $N, N, N^{\prime}, N^{\prime}$-tetramethylhexane-1,6-diamine (Acros Organics, used as received, toxic) for $24 \mathrm{~h}$ followed by a treatment in aqueous potassium hydroxide $\left(1 \mathrm{~mol} \mathrm{dm}^{-3}\right.$ ) for $1 \mathrm{~h}$ yielded electrodes coated with the hydroxide-exchanging polymer interface (Scheme 2) on the catalyst layer [2]. For methanol testing, the anode (E-Tek, $4 \mathrm{mg} \mathrm{cm}^{-2} \mathrm{PtRu}$ on carbon cloth with unspecified loadings of PTFE as binder) and cathode (E-Tek, $4 \mathrm{mg} \mathrm{cm}^{-2} \mathrm{HP}$ Pt black on carbon cloth with unspecified loadings of PTFE as binder) were similarly treated with the 
same intermediate loading of poly(vinylbenzyl chloride). Lamination was attempted by pressing the treated electrodes to the membrane at $3000 \mathrm{~kg}_{\mathrm{f}}\left(120 \mathrm{~kg}_{\mathrm{f}} \mathrm{cm}^{-2}\right)$ at both 60 and $100^{\circ} \mathrm{C}$; this was, however, unsuccessful and the electrodes and membrane were therefore simply assembled into the fuel cell fixture, non-laminated, at a torque of $50 \mathrm{~N}$ m so as not to further compromise the electrodes' and membrane's physical integrity with excessive pressing.

\subsection{Fuel cell testing}

The initial fuel cell testing was conducted on an Arbin Fuel Cell Test Station with a $25 \mathrm{~cm}^{2}$ test fixture. $\mathrm{H}_{2} / \mathrm{O}_{2}$ testing was conducted with $\mathrm{H}_{2}$ and $\mathrm{O}_{2}$ gases (BOC, laboratory grade) flowing at $2 \mathrm{dm}^{3} \mathrm{~min}^{-1}$ flow rates and controlled at $100 \%$ relative humidity with dew point humidifiers. Voltage $(V / \mathrm{V})$ and power density $\left(P_{d} / \mathrm{mW}\right.$ $\mathrm{cm}^{-2}$ ) vs current density $\left(i / \mathrm{mA} \mathrm{cm}^{-2}\right)$ steady-state polarization curves were galvanostatically collected using the integrated electronic load (from open circuit to high current densities), with data points being recorded after stabilisation for $10 \mathrm{~min}$ at each current density; before the curves were recorded the MEAs were conditioned by running at high current densities (50 $\mathrm{mV}$ potentiostatically-controlled discharge) for $30 \mathrm{~min}$, followed by open circuit operation for $15 \mathrm{~min}$. The MEA area resistance was monitored automatically by the electronic load (current pulse method), which gives routine order of magnitude values for resistances during fuel cell tests. DMFC testing was conducted with aqueous methanol (analytical grade, $2 \mathrm{~mol} \mathrm{dm}{ }^{-3}, 10 \mathrm{~cm}^{3}$ $\min ^{-1}$ pre-heated to the fuel cell temperature) replacing the $\mathrm{H}_{2}$ at the anode. The conditioning step was as for the $\mathrm{H}_{2} / \mathrm{O}_{2}$ tests. Temperatures and pressures are reported in the relevant figure captions. 


\section{Results and Discussion}

\section{$3.1 \mathrm{H}_{2} / \mathrm{O}_{2}$ fuel cell performances}

The $\mathrm{H}_{2} / \mathrm{O}_{2}$ fuel cell performances $\left(0.5 \mathrm{mg} \mathrm{cm}^{-2} \mathrm{Pt} / \mathrm{C}\right.$ electrodes $)$ are presented in Figure 1. Peak power densities of 90 and $110 \mathrm{~mW} \mathrm{~cm}^{-2}$ and in situ internal resistances of 1.0 and $1.1 \Omega \mathrm{cm}^{2}$ were recorded at 50 and $60^{\circ} \mathrm{C}$ respectively; these peak power densities are more than twice the peak power performance obtained by Agel et. al using epichlorohdrin-based alkaline membranes [11]. Tafel slopes from plots of $i R$ corrected voltages vs. $\log _{10}$ (current densities) were 71 and $60 \mathrm{mV} \mathrm{dec}{ }^{-1}$ at 50 and $60^{\circ} \mathrm{C}$ respectively. It was observed, from the deviation from linearity of the Tafel plots, that mass-transport limitations / interferences started to appear at as low as 30 $40 \mathrm{~mA} \mathrm{~cm}{ }^{-2}$ for the AAEM-MEA (the $i R$-corrected cell potentials were still above 0.8 V); this strongly suggests that mass-transport phenomena are significantly limiting performance, as expected with the use of electrodes that have not been optimised for use in AAEM-MEAs. This is further complicated by an additional water masstransport consideration i.e. water is now a reactant at the alkaline cathode as well as being present for membrane hydration: ${ }^{1} / 2 \mathrm{O}_{2}(\mathrm{~g})+\mathrm{H}_{2} \mathrm{O}(\mathrm{g} / \mathrm{l}) \rightarrow 2 \mathrm{OH}^{-}(\mathrm{mem})$.

For initial benchmarking purposes and before methanol testing, the $\mathrm{H}_{2} / \mathrm{O}_{2}$ fuel cell performance at $50^{\circ} \mathrm{C}$ of the $4 \mathrm{mg} \mathrm{cm}^{-2} \mathrm{PtRu} / \mathrm{Pt}$ black AAEM-MEA was evaluated (Figure 2) and compared to an analogous Nafion ${ }^{\circledR}-115$ MEA (tested under the same conditions). The peak power density obtained with the AAEM-MEA was $130 \mathrm{~mW}$ $\mathrm{cm}^{-2}$, compared to the $480 \mathrm{~mW} \mathrm{~cm}{ }^{-2}$ for the Nafion-MEA; this is a significant result as the peak power performance achieved with this early stage, and non-laminated, AAEM-MEA is $>25 \%$ of the performance obtained with proton-exchange materials that have been optimised over decades. Nafion-115 was selected as the benchmark PEM in anticipation of similar absolute resistances (Nafion is 3 times the thickness of 
the ETFE-based-AAEM but also of $3-5$ time higher conductivity) in order to minimise the number of variables affecting fuel cell performance; in situ internal resistances of $0.79 \pm 0.14 \Omega \mathrm{cm}^{2}$ were observed for the AAEM-MEA and $0.39 \pm 0.02$ $\Omega \mathrm{cm}^{2}$ for the Nafion-MEA. Tafel slopes of $70 \mathrm{mV} \mathrm{dec}{ }^{-1}$ for the AAEM-MEA and 61 $\mathrm{mV} \operatorname{dec}^{-1}$ for the Nafion-MEA were measured (at $i R$-corrected potentials above 0.8 V). A deviation from linearity of the Tafel plots (mass-transport limitations) started to appear at only $120 \mathrm{~mA} \mathrm{~cm}^{-2}$ for the alkaline-MEA, compared to $1050 \mathrm{~mA} \mathrm{~cm}^{-2}$ for the Nafion-MEA. This again highlights the need, with alkaline membrane MEAs, for optimisation of the electrode structures to minimise mass-transport related performance losses; mass-transport being a primary limiter of performance is fully consistent with the observed small (44\%) increase in power densities observed at $50^{\circ} \mathrm{C}\left(90 \rightarrow 130 \mathrm{~mW} \mathrm{~cm}^{-2}\right)$ when increasing the electrode catalyst loadings by $700 \%$ $\left(0.5 \rightarrow 4 \mathrm{mg} \mathrm{cm}^{-2}\right)$

\subsection{Methanol/ $\mathrm{O}_{2}$ performances}

As alkaline membranes were reported to exhibit only $30 \%$ of the methanol permeability of Nafion ${ }^{\circledR}$ [5], the ETFE-based AAEM was deliberately synthesised thin $(25 \mu \mathrm{m}$ base ETFE membrane thickness yielding a $51 \pm 2 \mu \mathrm{m}$ thick anionexchange membrane when fully hydrated) to offset the lower conductivities of alkaline membranes [8]. The methanol/ $\mathrm{O}_{2}$ performances are presented in Figure 3. Peak power densities of $1.5 \mathrm{~mW} \mathrm{~cm}^{-2}$ at $50^{\circ} \mathrm{C}$ increasing to $8.5 \mathrm{~mW} \mathrm{~cm}^{-2}$ at $80^{\circ} \mathrm{C}$ (with additional reactant pressurisation) were obtained and represent promising performances at such an early stage development of AAEM-MEA (the Nafion-115 MEA produced peak power densities in the range $30-80 \mathrm{~mW} \mathrm{~cm}^{-2}$ under the same testing conditions); the fact that a stable performance was obtained at a temperature as 
high as $80^{\circ} \mathrm{C}$ is significant as AAEMs are generally considered to be stable to temperature only up to $60^{\circ} \mathrm{C}$ [12]. Long term in situ tests are required to investigate this further.

These AAEM-MEA performances compete well with the $10 \mathrm{~mW} \mathrm{~cm} \mathrm{~cm}^{-2}$ peak power density obtained by Scott et al. with an alkaline-MEA containing a commercial quaternary-ammonium anion-exchange membrane (Morgane ${ }^{\circledR}-A D P$, Solvay S.A., Belgium), no alkaline interface polymer and $2 \mathrm{mg} \mathrm{cm}^{-2} \mathrm{Pt} / \mathrm{C}$ loadings, and tested at $60^{\circ} \mathrm{C}$, with 2 bar cathode pressure, and $80 \mathrm{~cm}^{3} \mathrm{~min}^{-1}$ methanol $\left(2 \mathrm{~mol} \mathrm{dm} \mathrm{dm}^{-3}\right)$ in aqueous $\mathrm{NaOH}\left(1 \mathrm{~mol} \mathrm{dm}^{-3}\right)$ [5]. Countanceau et al. report a peak power density of 18 $\mathrm{mW} \mathrm{cm}{ }^{-2}$ at $20^{\circ} \mathrm{C}$ with the same membrane and electrode Pt loadings as Scott et al. with methanol ( $\left.2 \mathrm{~mol} \mathrm{dm}^{-3}\right)$, but with even higher concentrations of aqueous $\mathrm{NaOH}(4$ mol $\mathrm{dm}^{-3}$ ); however $<0.5 \mathrm{~mW} \mathrm{~cm}^{-2}$ was obtained on the removal of $\mathrm{NaOH}$ from the fuel stream. Ogumi et al. obtained a peak power density of $6 \mathrm{~mW} \mathrm{~cm}^{-2}$ with another type of commercial anion-exchange membrane (AHA, Tokuyama, Japan) at $50^{\circ} \mathrm{C}$ with $4 \mathrm{mg} \mathrm{cm}^{-2} \mathrm{PtRu}$ at the anode supplied with $50 \mathrm{~cm}^{3} \min ^{-1}$ methanol $\left(1 \mathrm{~mol} \mathrm{dm}^{-3}\right)$ in aqueous $\mathrm{KOH}\left(1 \mathrm{~mol} \mathrm{dm}^{-3}\right), 1 \mathrm{mg} \mathrm{cm}^{-2} \mathrm{Pt} / \mathrm{C}$ at the cathode, and quaternised poly(4vinylpyridine) as a binding material. An interesting observation in that study was that the replacement of the $\mathrm{Pt} / \mathrm{C}$ at the cathode with non-noble $\mathrm{Ag} / \mathrm{C}$ did not lead to a significant drop in peak power - the use of non-noble metal catalysts being one of the potential advantages of using alkaline membranes in fuel cells.

\section{Concluding Remarks}

The results in this study, to the best of our knowledge, represent the highest peak power performances obtained to date with metal cation-free quaternary-ammoniumfunctionalised alkaline-membrane-MEAs and demonstrate that the presence of 
$\mathrm{M}^{+} \mathrm{OH}^{-}$in an aqueous methanol fuel is not needed to obtain a functioning alkaline membrane DMFC. The absence of metal cations is vital for elimination of carbonate precipitation in the electrode structures (a methanol / air fuel cell test with a low performing, non-ETFE, metal-cation-free alkaline-MEA was previously tested for 233 $\mathrm{h}$ with very low voltage degradation and insignificant membrane carbonation [2]). Further optimisation of the electrode formulation (e.g. applying the mass-transportoptimised catalysed Ti mesh electrodes of Scott et al. [13]), which bears in mind the added requirement for optimised water transport to the cathode (possibly by minimising loadings of hydrophobic PTFE in the cathode electrode architectures), will allow the realization of methanol fuel cell performances comparable to those already achieved with $\mathrm{Nafion}^{\circledR}$, but potentially with non-Pt-containing electrodes. Determination of the conditions required for optimised alkaline membrane/electrode lamination is also considered a key step towards further performance improvement.

\section{Acknowledgments}

We gratefully thank the Engineering and Physical Sciences Research Council (Grant GR/S60709/01) and the World Gold Council for funding, and EBIS Iotron Ltd. (Harwell, U.K.) for access to electron-beam facilities. 


\section{References}

1 J. R. Varcoe, R. C. T. Slade, Fuel Cells 5 (2005) 187.

2 J. R. Varcoe, R. C. T. Slade, E. Lam How Yee, Chem. Commun. accepted and inpress.

3 C. Coutanceau, L. Demarconnay, C. Lamy, J.-M. Léger, J. Power Sources in-press.

4 K. Matsuoka, Y. Iriyama, T. Abe, M. Matsuoka, Z. Ogumi, J. Power Sources 150 (2005) 27.

5 E. H. Yu, K. Scott, J. Power Sources 137 (2004) 248.

6 H. Herman, R. C. T. Slade, J. R. Varcoe, J. Membr. Sci. 218 (2003) 147.

7 T. N. Danks, R. C. T. Slade, J. R. Varcoe, J. Mater. Chem. 13 (2003) 712.

8 J. R. Varcoe, R. C. T. Slade, Solid State Ionics, 176 (2005) 585.

9 J. Chen, M. Asano, Y. Maekawa, M. Yoshida, J. Membr. Sci. in-press.

10 R. F. Silva, M. De Francesco, A. Pozio, J. Power Sources 134 (2004) 18.

11 E. Agel, J. Bouet, J. F. Fauvarque, J. Power Sources 101 (2001) 267.

12 T. Sata, M. Tsujimoto, T. Yamaguchi, K. Matsusaki, J. Membr. Sci. 112 (1996) 161.

13 E. H. Yu, K. Scott, J. Appl. Electrochem. 35 (2005) 91. 
Scheme 1: The synthesis of radiation-grafted ETFE alkaline anion-exchange membrane (AAEM).

Scheme 2: The synthesis of the alkaline polymer electrochemical interface.

Figure 1: The $\mathrm{H}_{2} / \mathrm{O}_{2}$ fuel cell performances (no back-pressure) of the $0.5 \mathrm{mg} \mathrm{cm}{ }^{-2}$ $\mathrm{Pt} / \mathrm{C}$ AAEM-MEA at $50^{\circ} \mathrm{C}(\bullet)$ and $60^{\circ} \mathrm{C}(\mathrm{O})$.

Figure 2: The $\mathrm{H}_{2} / \mathrm{O}_{2}$ fuel cell performance at $50^{\circ} \mathrm{C}$ (no back-pressure) of the $4 \mathrm{mg}$ $\mathrm{cm}^{-2}$ catalysed AAEM-MEA $(\bullet)$ compared to an analogous Nafion115-MEA (O, the same electrodes but coated with $0.8 \mathrm{mg} \mathrm{cm}{ }^{-2}$ Nafion dispersion and pressed at $120 \mathrm{~kg}_{\mathrm{f}}$ $\mathrm{cm}^{-2}$ at $135^{\circ} \mathrm{C}$ for $\left.3 \mathrm{~min}\right)$.

Figure 3 The methanol/ $\mathrm{O}_{2}$ performances of the $4 \mathrm{mg} \mathrm{cm}{ }^{-2}$ catalysed AAEM-MEA listed from lowest to highest peak power performances: $50^{\circ} \mathrm{C}$ (no back-pressure), $60^{\circ} \mathrm{C}$ (no back-pressure), $60^{\circ} \mathrm{C}$ ( 2 bar and 2.5 bar back-pressures respectively at the anode and cathode), and $80^{\circ} \mathrm{C}$ ( 2 bar and 2.5 bar back-pressures respectively at the anode and cathode). 